\title{
A Case of Double Socialisation in the Social Sciences
} The Experience of Chinese Researchers Trained in France

\section{Gilles Guiheux and Simeng Wang}

\section{CpenEdition \\ Journals}

\section{Electronic version}

URL: http://journals.openedition.org/chinaperspectives/8398

DOI: 10.4000/chinaperspectives.8398

ISSN: 1996-4617

\section{Publisher}

Centre d'étude français sur la Chine contemporaine

\section{Printed version}

Date of publication: 31 December 2018

Number of pages: 21-30

ISSN: 2070-3449

\section{Electronic reference}

Gilles Guiheux and Simeng Wang, "A Case of Double Socialisation in the Social Sciences ", China Perspectives [Online], 2018-4 | 2018, Online since 31 December 2019, connection on 24 March 2020 URL : http://journals.openedition.org/chinaperspectives/8398; DOI : https://doi.org/10.4000/ chinaperspectives.8398 


\title{
A Case of Double Socialisation
}

\section{in the Social Sciences}

\author{
The Experience of Chinese Researchers Trained in France
}

\author{
GILLES GUIHEUX AND WANG SIMENG
}

\begin{abstract}
This article discusses the epistemological issues raised by the internationalisation of the social sciences as they affect the case of students from the People's Republic of China who are trained in social sciences in France and return to pursue their career in higher education and research in China. The aim is to assess whether the epistemological differences between the two academic worlds may give rise to any professional difficulties in this many-sided scientific socialisation. Although our qualitative enquiry has revealed a number of differences, the problem of the availability of professional opportunities does not seem to have a distinctively epistemological dimension.
\end{abstract}

KEYWORDS: internationalisation, social sciences, Chinese students, France, China, scientific socialisation, epistemology, higher education, research.

\section{Introduction}

$\mathrm{T}$ he internationalisation of scientific activity takes a number of different forms: researchers' participation in conferences, the pursuit of research projects across borders, or the establishment of international research programs. It depends upon a range of resources, such as professional associations, scientific networks, journals, publishers, links between universities, scholarships for visiting students and scholars, travelling allowances, etc. In comparison with the natural sciences, the human and social sciences are more affected by the local social, political, and historical contexts. Since the researcher's working language is to a large extent his/her local language, and the public demand is often linked to problems specific to the overall direction of the country, one might infer that the human and social sciences have a more national epistemology.

At the same time, international scientific exchanges are not haphazard, and they take place within relations of power and dominance in the intellectual field. In the domain of the social sciences, Syed Farid Alatas (2003) has set out three distinct areas. The "centre" is occupied by countries where theories are generated and are subsequently diffused throughout the world: the United States, Britain, and France. Deeply involved in international cooperation, they have their own way of doing social science: their work is carried out in their own languages, based on concepts elaborated on home ground and in accordance with research agendas under their control. On the opposite side are the "peripheral communities" of social sciences bringing together scientifically dependent territories. They borrow their research agendas, theories, and methods from the "centre," and are mostly from the Global South. Their aim, since the early 2000 s, has not been to become exporting countries but to adjust the imported research agendas to their national context. Finally, between the centre and the periphery lies a "semi-peripheral" space occupied by Australia, Japan, Germany, and the Netherlands in particular. Occupying an intermediate space, these countries are certainly dependent on the centre but they also exercise considerable influence on the scientific communities on the periphery.

The direction taken by the internationalisation of social sciences varies in accordance with the particular national scientific community in question. It is especially affected by the historical relationship of domination between the countries of the Global North and the Global South. So the international scientific exchanges are often grounded in the continuing forms of co-operation built upon historical relationships, especially those linking the colonised territories to the colonisers (Garneau and Mazzella 2013). However, new university poles of influence are emerging, which to a certain extent put the old hierarchies of knowledge into question (Gérard and Cornu 2013; Dedieu 2003). This is the case for the Maghreb countries (Mazzella 2009), but also for Malaysia, South Korea, Cuba, and even South Africa. Their forms of knowledge and their legitimacy within the national space provide the basis for these variant poles of influence, sometimes on par with geopolitical criteria (Gérard and Wagner 2015: 8).

In addition, the social sciences that have been disseminated throughout the world are methodologically and theoretically rooted in their European and North American contexts and are not always immediately transferable into non-Western contexts (Kuhn and Weidemann 2010). Some sections of European and North American social sciences are trying, not without difficulty, to disentangle themselves from their imperialist reflexes. Taking her inspiration from subaltern studies, postcolonial studies, and the criticisms levelled at eurocentrism, Laurence Roulleau-Berger, for example, proposes "the invention of post-Western social sciences" (Roulleau-Berger 2011, 2015). A project for equal participation by all scholars from a wide range of different national perspectives calls for reflection on its epistemological basis, and that is the question at the heart of this article.

If one takes the example of Western studies devoted to China, they have undergone considerable changes over the last three decades. They have ceased to be monographs or studies aimed at a readership concerned with 
global geopolitics. ${ }^{(1)}$ China has now become an object of study just like any other area. Social scientists specialising in Chinese matters make use of the same methods and similar theoretical references, whether they are Chinese or foreigners. (2)

This article discusses the epistemological issues in the internationalisation of the social sciences as attested by the case of students from the People's Republic of China who undergo their training in social sciences in France and return to pursue their career in higher education and research in China. Since the 1980s, recruitment into elite circles in China has required the candidate to possess an increasingly "international" profile (Derouet et al. 2017: 28). Overseas residence and training during higher education are considered beneficial and are encouraged by public policy (Huang 2010: 34). For the Chinese authorities it is a question of enabling the acquisition of knowledge in order to overcome developmental backwardness; this applies equally to social sciences meant to formulate recommendations in the face of the societal challenges confronting the country (urbanisation, migration, social mobility, etc.). More recently the goal has certainly changed: it is now a matter of confirming China's position as a global scientific power or, as Alatas puts it, a "central" nation.

The encouragement of movement overseas by students and intellectuals is not unique to China. At the global level, the number of students studying abroad rose from 0.8 million in 1975 to 1.7 million in 1995, and to 4.1 million in 2013 (according to UNESCO figures ${ }^{(3)}$ ). So it has more than quadrupled in 40 years. Among the large-scale social factors shaping the international movement of students there is not only the liberalisation of education services, which have been marketised, but also the establishment of global university classification systems and public policies for handling the reception of foreign students, for immigration, and for the repatriation of expertise.

In the case of China, in 2016 there were 544,000 citizens of the PRC studying abroad; (4) 30,000 were supported financially by the state, 16,000 by their companies, and 482,000 were self-financed (i.e. over 88\%). (5) In 20152016, France was seventh among the recipient countries, hosting $2.8 \%$ of Chinese studying overseas, far behind the United States (32.9\%), Canada (12\%), Britain (9.5\%), Japan (9,8\%), Australia (8.3\%), and South Korea (6.7\%). ${ }^{(6)}$ In 2015-2016 the Chinese student population in France stood at 28,043 individuals, which is about $10 \%$ of the foreign student population there, and puts China in second place among the countries of origin. ${ }^{(7)}$ For the Chinese government in the twenty-first century, sending their students overseas is no longer just a matter of acquiring knowledge but also of increasing the internationalisation of higher education when they return home. The government's objective is "to bring about the emergence of high quality universities with a global reputation and centres of excellence capable of competing on a global scale" (Huang 2007: 58), or in other words, to raise China among the ranks of the major scientific powers.

Alongside investigations dealing with the development of dominant intellectual relations, other research is concerned with the international mobility of students and scientists in a more microsociological perspective, to study the variety of their trajectories and lived experiences. The knowledge and intellectual capital - internationally accumulated or not - opens up processes of reproduction, or else recomposition (Gérard and Wagner 2015). Hamidou Dia (2015), for example, shows that the knowledge acquired by Senegalese Arabists allows them easier access to their nation's elite. In other countries, the obverse case of certain elites being transformed on the basis of knowledge acquired in the course of their international training, as dis- tinct from their local knowledge, is a remarkable phenomenon. Here we could mention the African political and military elites who switch back into finance (Bourgouin 2011). The studies of the social trajectories followed by the national elites show the national stakes in the public policies for internationalisation and their effects, expected or not, in terms of social mobility and access to employment. They also show their effect on social inequalities, in class terms, between the mobile and non-mobile members of each nation. In this respect, there are a number of different actors - governments, educational establishments, scientific communities, families, and individuals - and of diverse or mixed operational logics, overlaying and sometimes contradicting each other, which lead in the end to a combination of heterogeneous movements (Garneau and Mazzella 2013).

The question of the epistemological differences between Chinese and French social sciences is posed when one considers the paths taken by Chinese students coming to gain their doctorates in France and then returning to take up university positions in China. What is at issue here is the double scientific induction undergone by individuals who have been trained according to the norms of French and Chinese institutions or, as Alain Coulon (1997) put it, who have acquired a double "affiliation." In the opinion of some, such students are confronted with major difficulties arising from the way doctoral studies are organised in France. ${ }^{\left({ }^{8}\right)}$ For our part, we are interested in the conditions of appropriation and re-appropriation of knowledge and new scientific practices, that is, in the apprenticeship modalities specific to France on the one hand, and the conditions for entry into the Chinese scientific labour market on the other. Our aim is to investigate the gaps between the two academic worlds and the existence or non-existence of difficulties caused by this multiple form of scientific induction: to what extent does a young researcher trained in France find himself on returning to China in a state of tension due to a scientific environment different from his previously acquired commitments or skills?

Following some exploratory interviews, ${ }^{(9)}$ an open questionnaire was sent to 29 doctoral students and graduates, half of whom have since gone on to take up university positions in China. ${ }^{(10)}$ They spent an average of seven years in France, a large number of them having come to France for a Master's degree. These residential study periods all took place after the year 2000 , and over $40 \%$ after 2010. A large majority, 22 out of 29 , received financial support for their doctoral studies. The questionnaires were circulated

1. We have in mind the times of expert sinology and area studies supported, in the case of the United States, by diplomats and military personnel (Szanton 2003).

2. This is one of the conclusions drawn by Rocca (2008) and Roulleau-Berger et al. (2008).

3. UNESCO Report on Science, https://fr.unesco.org/node/252299 (accessed on 30 April 2018).

4. 2017 年出国留学趋势报告 (2017 nian chuguo liuxue qushi baogao, 2017 Report on the development of overseas studies), http://www.eol.cn/html/lx/report2017/mulu.shtml (accessed on 30 March 2018)

5. Ibid.

6. Ibid.

7. Ibid.

8. These alleged difficulties were criticised in a blog: Jean-Louis Rocca, "De la misère des thésards chinois en France," Médiapart, 2016, https://blogs.mediapart.fr/roccabeijinggmailcom/blog/ 250516/de-la-misere-des-thesards-chinois-en-france (accessed on 30 April 2018). The tests described by these two writers are similar to "the time of being an outsider" analysed by Alain Coulon. The new arrivals, who are moreover foreigners, have to assimilate codes that define the organisation of the academic world and are often opaque or even impenetrable. Coulon shows how the student passes through a succession of different tests before feeling "assimilated" to his new environment.

9. There were about ten of these discussions with young colleagues with qualifications in Social and Human Sciences (SHS), who were either seeking employment on the Chinese job market or already employed.

10. A table of information on all our informants is to be found in the Annex 
through our acquaintanceship network, which explains that nearly half (13 out of 29) are sociologists, (11) but all the human and social science disciplines are nonetheless represented. Relying on the data from this enquiry, the first part of our article sets out in detail the specific gains from their university training in France. The second section goes back to consider their value in terms of the Chinese academic job market.

\section{The specific gains from university training in France}

The questions put to our interviewees allow us to identify the specific gains from university training in France, in terms of learning about methods and concepts, the demand for intellectual freedom, and the assimilation of new categories of thought. The replies reveal the epistemological differences produced by their stay in France in comparison with what they had already learnt in China.

\section{Learning new categories of thought}

Undergoing training in France is first of all a matter of learning the French language. As one of our interviewees emphasised, to speak and write the French of the social sciences is also a matter of thinking differently (I16):

For me, what I learnt that was special and unique is the scientific language that is a kind of rhetoric specific to France. To be more precise, what I learnt was how to use the language in a variety of different circumstances: oral presentation, preparing a doctoral thesis for publication, handling personal exchanges, publishing articles, teaching and training, etc. (...). Language is also a way of thinking.

So it is not just a question of mastering new techniques of expression or persuasion, but also of getting to know another way of conceiving the world, and giving up their habitual way of thinking and a certain conditioning inculcated by their initial intellectual development in China. Practicing another language is in effect a denaturalisation of one's own thought categories. ${ }^{(12)}$

Being trained abroad, in France in this case, allows for the deconstruction of the categories of the social sciences through the prism of the new language in which these young researchers pursue their apprenticeship (I16):

For example, the term that we often find translated into French as "identité" may be either shenfen 身份 or rentong 认同, and neither of these terms conveys the multiple meanings of the original. Other examples could be "identification," "dynamique identitaire," or "subjectivation." The meaning of the expression "insertion professionnelle" is related to the background French historical context, such as the importance of the welfare state and public sector employment. But there is no corresponding term in the English or Chinese contexts. One might translate it into English as "labour market integration" or into Chinese as zhiye ronghe, 职业融合, but that does not sound right. (...). There are other examples where it is difficult to use a French term to analyse a Chinese situation. One could cite the example of "social stratification," which has a different history in China and in France. Consequently the French "catégories socioprofessionnelles" cannot be applied directly to Chinese society. The same could be said of the term "cadre" (in the broad sense of its use in French sociology), which is difficult to apply to any enquiry into Chinese society (where the term refers to Party cadres).

Moving from the Chinese to the French context allows one to escape from a substantive and essentialist vision of concepts in the social sciences. As Yves Chevrier puts it, it allows one "to revisit and criticise the concepts and taxonomies in the social sciences because they are implicitly or explicitly modelled on the phenomena, regular patterns, and myths that arose in the developmental course of the European historical and cultural field" (Chevrier 2003).

In fact, several informants, some involved in translating leading French sociologists into Chinese, have brought up the difficulty of finding a Chinese translation for anthropological terms such as "religion," "patrimony," "rites," "bride price" (12), or "personal networks" (I3). To take the example of "religion," there is indeed a Chinese translation, zongjiao 宗教, but as a category with a Western origin it is ill-suited to describing the Chinese reality; moreover, imported at the turn of the twentieth century as part of a reorganisation of established knowledge, it had the further effect of remoulding the religious field itself (Gossaert 2007). By contrast, the term "personal networks" may be translated into Chinese as geren wangluo 个人网络, but that does not have the richness of the proper Chinese term renji guanxi 人际关 系, which has been widely discussed in the literature (Gold, Guthrie, and Wank 2002). These discussions contain precise documentation of the difficulties caused by using originally European concepts in a Chinese context. Although our interviewees have acquired a clear understanding of the contextual nature of the tools employed in the social sciences, that does not mean that they do not make every effort to use those concepts that they believe to share common ground and that are capable, for the most part, of throwing light on social reality, wherever it may be. One of them gave the following expression of confidence in using the tools acquired in France for working in China: "Most of the French sociological concepts can be used for studying Chinese society after in-depth discussion" (116). These tools are often linked to methods that the researchers learnt in France, but the heuristical power of which they will test in China.

\section{Apprenticeship in methods and concepts}

When they were questioned on what they have learnt that, in their view, is specific to their university training in France, our interviewees mentioned the ways of grasping scientific questions, that is to say, both methods and content. A major acquisition was the ability to "look at things and to think about them critically" (11), but it is not unique to French cases. The practice of interdisciplinary studies seems perhaps more distinctive. Several of them mentioned the possibility of making simultaneous use of concepts borrowed from several disciplines, such as sociology, anthropology, economics, and psychoanalysis (I1 and I14). In the case of I14, her enquiry took place in China, and dealt with the emergence of NGOs in charge of problems neglected by the public health institutions. Another interviewee mentioned the possibility, provided by his institution, of following a broad range of

11. We are conscious of the effects of the writers' social position (their training, discipline, professional development and status, research topics, institutional affiliation etc.) on the interviewees' recruitment and their profile.

12. A recent issue of the journal Tracés, "Traduire et introduire les sciences sociales d'Asie orientale" (2017), is concerned with this set of problems arising from the circulations between East Asia and the West. 
learning experiences peripheral to his main course of study. 123 told us that "Interdisciplinary studies and analyses combining different theories are far more widespread here than in China." In their pursuit of these interdisciplinary approaches, we can see not only a characteristic of the social sciences training received in France but also of area studies (assuming the probable hypothesis that most of our interviewees pursue their enquiries in China). Indeed, one of the major advantages of working in a geographical or cultural sphere is being able to experiment with a combination of approaches without being imprisoned by disciplinary boundaries even if, as Elisabeth Longuenesse and François Siino insist, "to be truly fruitful, these approaches must be reasoned, methodical, and fully in control of their practical implementation" (2005: 105-6).

The time spent in France allowed the young researchers to discover new qualitative and quantitative methods in which they had not been trained, such as the variety of interviewing methods (14), participant observation (I6), attention to life stories, techniques for analysing textual data (116), making use of databases and geographical information systems (I5), and qualitative enquiry methods in general (I22). In France the doctoral thesis is in fact conceived as a period in which the young researcher submits data gathered on the ground to a wide range of treatments; mastering the various methods for collecting and using data is part of the training.

On their arrival in France, some students discovered how to conduct field studies (129), and they were above all encouraged to reflect upon their own position as investigators. One of them (11) mentioned the importance of subjective responses and reflection on experiences on the ground, while another (12) emphasised learning to make a "conscious reflection on the object and the situation of the enquiry." More generally, an enquiry (15) involves the contribution made by an epistemological reflection that he had not taken into account until then. Conscious reflection has become an imperative in all the social sciences, particularly in the directions followed by the work of Pierre Bourdieu (Bourdieu 2003, 2004): it compels the researcher to apply his analytical tools to his own biographical experience and to undertake the task of self-analysis. For the sociologist in particular, this self-positioning consists of conducting a critical analysis not only of his own scientific practices but of the social conditions for all intellectual production.

With regard to intellectual tools, the young interviewees mentioned a whole series of concepts to which they were first introduced in France. While some of these were devised by French writers - for example, "governmentality" (11) and "collective memory" $(14,19)$ - others belong to the general development of the social sciences in the last decades, and are used by historians, geographers, political scientists, and sociologists: for example the "production of space" (19), "secularisation" (14), "hegemony" (I1), and "social identity" (19).

Among the scholars quoted as having a major influence on the intellectual development of these young Chinese researchers are the founding fathers of French and European social sciences: Alexis de Tocqueville, Emile Durkheim, Marcel Mauss, and Max Weber. One of the interviewees emphasised that in the French training there is greater emphasis "on the major intellectual traditions" (119). There are also writers of the post-World War Two generation whose importance for some is more specifically national - for example Paul-Henry Chombard de Lauwe and Henri Coing, who pioneered urban studies - and there are others with a more global reach: Michel Foucault, Pierre Bourdieu, and Robert Castel. They also mentioned sociologists, anthropologists, historians, jurists, and economists who are still productive and widely recognised: Claude Dubar, François Dubet, Jacques Commaille,
Maurice Godelier, Pierre Rosenvallon, Jean Carbonnier, and Robert Boyer. The interviewees' stay in France was also an occasion for them to get to know foreign writers such as Ulrich Beck and his theory of modernity, and Manuel Castells (who taught at the École des Hautes Études en Sciences Sociales before embarking on his career in the United States) and his notion of "social networks." Later we will see how the Chinese researchers would make use or not of these sources in their own scientific production on their return to China.

Since the large majority of these doctoral students and graduates are working on Chinese material, it follows logically that their doctoral training was also their opportunity to become acquainted with the French specialists on China, who also cover a variety of disciplines. They mention historians Marianne Bastid, Marie-Claire Bergère, Jacques Gernet, Alain Roux -, a geographer specialising in the Chinese diaspora - Emmanuel Ma Mung -, a political scientist - Jean-Philippe Béja -, and an economist - Thierry Pairault -, to mention only the leading figures among them. A number of the interviewees also mentioned the researchers in their own units or those supervising their work. In the last part of this article, we will see how Chinese researchers mobilise these resources in their own scientific production upon their return to China. Another way of making good use of what they have learnt is by collaborating in projects with French researchers, or in producing translations.

\section{The demands of intellectual freedom}

The interviewees expressed comparatively favourable views in their assessment of the French university system. Compared with the set-up in China, the French system offers more freedom to choose what to study and the methods to be used (I3):

The professional environment in a French research centre is very different from China. I have more freedom to express my own ideas with both my supervisor and my colleagues.

In the end, that might be their reason for choosing a career in France instead of returning to China. As 14 puts it:

I have never tried to find a position in China. It is for reasons of intellectual freedom that I am staying in France. ${ }^{(13)}$

According to another interviewee, "there is greater freedom in choosing one's area of research" (112). There is no doubt that in France, particularly in the social sciences, research is carried out in a framework that permits greater independence of mind, especially with regard to the public sphere, even though the state is the main source of funds for scientific research. In the case of China, censorship and self-censoring are common practices. ${ }^{(14)}$ By definition, French social sciences see themselves as critical sciences. ${ }^{15)}$

13. I4 was the only one of our interviewees who chose not to return to China upon finishing his doctorate.

14. On research conditions within the Chinese authoritarian regime, see Heimer and Thorgersen (2006: 81-128).

15. By the term "critical" here we mean the researcher's intellectual freedom, not the alternative meanings of "critical sociology" and the "sociology of criticism." The first meaning refers us to a Marxist reading aimed at unmasking the concealed relationships of domination, while the second is concerned solely with its opposite, a pragmatic understanding of the points of view of the actors involved. 
In China most of such studies are supported by public funds in response to national or provincial needs, or the requirements of local administrations. They are essentially expert reports and are therefore constrained by the current political line (Zhang 2008). The permanent risk of censorship hangs over any perspective critical of public policies. On returning to China, our interviewees must adjust their research practices in line with the prevailing norms, and intellectual freedom is a principle subject to compromise. In this regard, some very concrete examples were given. In one interview, I29 mentioned the arrangement for exchanging views, which does not exist in China:

In France, we are accustomed to participating in discussion groups on concepts and research methods. What we have done is open to discussion, whereas in China students have no such opportunities.

The main point here is the existence of institutionalised spaces where research is discussed. Freedom here is what puts the doctoral student at a distance from his thesis supervisor. In China, the relationships of doctoral supervision are quite different, since the candidate is often financed by the collective research project supported by his thesis supervisor, making the junior researcher inevitably dependent on him. This was borne out by one of the interviewees (19):

To be able to conduct sociological research independently, that is the big difference from doctoral preparation in China. The Chinese system is characterised by the close relationship between the doctoral candidate and his supervisor, which amounts largely to a relationship of dependence. My studies in France were a positive help in enabling me to carry out my research in an independent manner.

Here the difference is a matter of the teaching relationship and the conditions for training, in which debate plays a considerable role. One of our interviewees brought up a fairly common experience among Chinese doctoral students, for whom the encounter with this freedom is also a challenge (I16):

At the beginning of my doctoral studies, I had many problems with my supervisor. Communication between us was not easy. I hoped to get from him very clear answers to my questions, but his replies were always very general; he let me find my own way, raising problems. At the same time he made high demands on me and I did not get his approval. (...) Once the problems were formulated properly, the communication between us improved. (...) I myself matured; I developed research pathways in an independent way.

Here the French supervisor was expecting his student to be autonomous in devising his own scientific approach and to show some intellectual creativity, whereas the Chinese student seems to have been trained more to follow the directions given to him by his tutor.

Another interviewee sums up in a single paragraph the dual demand for intellectual independence and critical acumen specific to the training in France, which he associates with the practice of interdisciplinary study and the expectation of the researcher's objectivity mentioned above (I21):

The independent thinking and the critical consciousness to be found in the French academic tradition are relatively rare in Chinese academic training. In conjunction with this, in the self-reflexivity prac- ticed by the French human sciences, there is a strong interdisciplinary element, that is, the need to reflect upon the investigation being carried out. This means turning attention back onto the reality itself, integrating the multidisciplinary research methods, and even achieving a philosophical level of reflection. Moreover, French scientific thought is plural in the directions it may take; starting from a single fact, it can move in a variety of different directions (...) whereas in China one is trained in a specific approach.

In sum, what is being expounded here is the variety of possibilities permitted by the social sciences. It seems to us that this is indeed one of the mainstays of the social sciences as they are practiced in France. Wherever they may be, all researchers, from the junior to the most experienced, have to follow the prevailing ways of designing projects, which they then submit to their funding agencies or their employers; in these documents they must give precise indications of the theoretical framework to be followed, the enquiries to be conducted, the hypotheses to be tested and the results obtained. And yet their research cannot be creative if the enquiry itself, even while following its proposed lines of enquiry, does not bring its own objects to light, because these are not identified from the outset. The researcher must remain alert and open to unexpected discoveries; even if his research is carried out within a pre-established framework, it still remains unpredictable, especially for qualitative studies (O'Brien 2006). In the same way, chance plays a role in writing it up, for it is not a simple matter of giving form to a thought flowing directly from a source (Becker 2002; Zaki 2006). At the moment of writing, the collected data and its interrogation may give rise to a plurality of texts. It is this freedom faced by the young researchers that is difficult to put into practice but has to be preserved throughout the work in process, both during the enquiries and in writing them up. That is the point made by one of our interviewees, albeit in his own words: "In France, there is a greater space of freedom for the researcher" (126).

Other advantages to university training in France were mentioned: access to more publications - "with regard to published works, there are far more resources than in China" (112)-, greater international exposure, and "more opportunities for international exchanges" (I26). In fact there is little doubt that, in both France and China, there are large differences between the universities themselves, depending on their position in the hierarchy of establishments, their financial and pedagogical resources, and their national and international reputation. These differences are all the more pronounced in China because its public policy for higher education officially sanctions the discrimination between the universities: at the top are the elite establishments funded to a great extent by the central government, then come the second or third-tier ones under the control of the provincial and local authorities. ${ }^{(16)}$

The young Chinese researchers' understanding of the way the French academic system operates is therefore not acquired without encountering obstacles and difficulties. These are normal experiences in getting accustomed to university life but, as Alain Coulon shows, they are far greater for foreign students. Altogether, our interviewees saw real value in a number of aspects that they contrasted with the practices of scientific training in China: the acquirement of an interdisciplinary body of knowledge, rather than a monodisciplinary one, the exercise of critical and independent thinking -

16. Cf. Wu Shulian 武书连, 中国大学评价 (Zhongguo daxue pingjia, Classification of China's Universities), 2018, http://edu.sina.com.cn/gaokao/2018-02-25/doc-ifyrwsqh9613316.shtml (accessed on 30 April 2018) 
thanks to the places reserved to allow its expression -, and, as expected, the familiarisation with new writers. Now we shall turn to a consideration of how our interviewees re-accustomed themselves to the academic world in China.

\section{Re-affiliation to the Chinese scientific system}

Our enquiry has provided us with some aspects of the conditions faced by our interviewees on returning to China and their professional integration. This may well be considered the moment when the value of their abilities acquired in France was put to the test. It throws light on the advantages and the disadvantages of their French university training.

\section{The students returning from abroad compete with one another}

For a long time the Chinese scientific job market has attached value to periods of study abroad. That was actually the reason why in 1996 the Ministry of Education established the China Scholarship Council (Guojia liuxue jijin weiyuanhui 国家留学基金委员会) as a dependent institution for funding doctoral studies overseas. ${ }^{177)}$ The obligation imposed on the funding recipients to work for at least two years on completing their doctorate is also part of China's strategy to create a body of scientists who would be well integrated into international circles, and it partly explains the increasing number of students returning from overseas, which has risen from $70 \%$ in the 1990 s to nearly $100 \%$ at the present moment. Some establishments have introduced particularly radical policies. The case of 17 is an example: she was enrolled in a first-rank national university - where she had previously trained - even before she defended her thesis in France in 2011, a year when several prime universities chose to appoint only those with a foreign doctoral degree.

In this market, the students trained in France are also competing against returnees from other countries. Several of the interviewees $(15,19)$ reckon that the comparative advantage of France is not so important in comparison with their fellow returnees from the English-speaking countries. Assuming that most of those studying in France are working on their native country, such a consideration only becomes significant in relation to the marginal position on the international academic scene of Chinese studies conducted in France. We can measure this marginality by the numbers of French native researchers on the editorial boards of some of the major international journals that specialise in the study of contemporary China: one out of 20 for China Quarterly, one out of 34 for the China Journal, and two out of 64 for the Journal of Contemporary China. The presence of colleagues from North America (mostly from the US but some from Canada) on the same boards is massive, standing at 15 , nine, and 40 respectively.

Also the situation is rapidly changing (19):

If you are talking about the time when few students went abroad, then, yes, students who earned their degree in France did have an advantage. But for some time now, that has no longer been so clear, since all our colleagues have foreign experience.

So the situation nowadays is far less easy than about ten years ago. Another consequence of the political initiative to send students abroad is that many young researchers trained at home are now looking for a job. What is more, the recruitment criteria have changed: "From now on, what matters is the quantity of academic production (i.e. publications)" (12).

\section{Recruitment criteria based on publication figures}

Chinese universities, especially the best ones, ${ }^{(18)}$ are now making use of selection criteria supported by the hegemonic arrangements on the international scene, namely the bibliometric tools devised in the English-speaking world. One of the interviewees recognised this situation: "The market [for scientific employment] is global and its criterion is publication" (I8), making it clear that in order to be appointed, it is imperative to have been published in international journals, especially in those to be found in the Social Sciences Citation Index SSCI. ${ }^{(19)}$

This index is a database of references set up in 1973 by the Institute for Scientific Information (currently part of the Thomson Reuters company), which includes about 3,000 scientific journals covering 55 human and social science disciplines. In 2009, according to calculations by Michèle Dassa and Denise Pumain (2010: 8), the 24 journals published in France that are listed in the $\mathrm{SSCl}$ represent only $1.19 \%$ of its coverage. Among the 2,000 human and social sciences journals, French journals are very clearly under-represented in comparison with the English language ones, of which $53.8 \%$ are American (1,084 journals) and $24.75 \%$ are British (498 journals). This is one of the explanations for the advantages on the Chinese market enjoyed by returnees from the English-speaking countries, because they are better equipped to publish in journals listed on the reference bases, and especially the SSCl. As E12 observed:

Basically, in China publishing in a journal that is not on the $\mathrm{SSCl}$ does not count for anything. We should get the French publications better integrated into the $\mathrm{SSCl}$ in order to allow them to be taken into account in the assessment procedures of Chinese universities. But in reality that is very difficult.

\section{According to another interviewee (19):}

With regard to foreign publications, my university only recognises those listed on the $\mathrm{SSCl}$ and the $\mathrm{AHCl}$ (Arts and Humanities Citation Index), which are set up in the United States. French journals are very sparsely included. So in general, if we publish in French our university pays no attention to our work.

On the $\mathrm{AHCl}$ database, France only accounts for $5.66 \%$ of the journals listed, with 66 titles included, against $42.2 \%$ for the United States (492 titles) and 16.9\% for Britain (197 titles) (Dassa, Kosmopoulos, and Pumain 2010: 8).

17. The CSC also funds the travel of students at every level, first degree, master's degree, doctorate, as well as teaching and research staff pursuing their studies in China.

18. To cite only the best known among them: Peking University, Tsinghua University, Fudan University, and jiaotong University.

19. On the dominance of the $\mathrm{SSCl}$ index on scientific research, and specifically in SHS research, see the debates and discussions led by Seglen (1997), Casadevall and Fang (2014), and Contat and Gremillet (2015). On the imperative for doctoral students in Chinese universities to publish in listed journals, see "Publish or Perish: The Dark World of Chinese Academic Publishing," http://www.sixthtone.com/news/1003146/publish-or-perish-the-dark-world-of-chinese-academic-publishing (accessed on 3 November 2018). 
One of the interviewees summed up, in the terms below, the comparative advantages on the Chinese job market for doctoral graduates trained in China, France, and the English-speaking countries (19):

If I compare my colleagues with different academic training, each has its own advantages. Those who have come back from the United States, Britain, and other English-speaking countries are able to write better in English and have the ability to publish in $\mathrm{SSCl}$ journals. Those who have trained in China itself are more familiar with the ways of submitting and presenting research projects to the [national] funding institutions. Those who obtained their doctorate in France do not have as much linguistic advantage as if they had mastered the English language; and they are also unaware of the procedures for submitting research projects.

Some of the doctoral students trained in China favour short-term foreign visits (lasting a semester or a year) in order to have that international experience, rather than completing their thesis wholly abroad. We should note that a number of our interviewees are completing their doctorates within the framework of Franco-Chinese joint tuition, which partially facilitates their post-doctoral recruitment in comparison with students preparing their thesis in a French institution with no links to the Chinese research world. The majority of our interviewees are opting to return home after their studies in France, going back to the same city (and even to the same university) where they were educated before leaving for France. That shows the importance of building and maintaining the already established scientific networks for recruitment in China, which is the strategic path taken by 17 prior to returning to the job market there. Here another criterion for evaluation comes into play: the ability of these young scientists to lower their demand for financial support to match the supply of jobs advertised in China. What is striking here is that there is no question of their scientific abilities, but rather of knowhow and the tactics that must be deployed in the academic world: to be able to write an article in the format expected by the journals listed in the bibliometric databases; to master the application procedures to funding programs from Chinese research institutions, to build up a personal network in Chinese academic circles in order to win an appointment, etc.

\section{The need for firm control over the body of references}

We still have to assess the contribution of the social science training in France to the Chinese job market: how is this acquisition evaluated by the institutions in light of the goals that they set for their teaching staff and researchers? In order to answer this question we have analysed the references used by one of our interviewees in his publications. He spent three years in France, from 2005 to 2008, to work on his doctorate under the joint tuition of a French and a Chinese supervisor. We gathered a body of nine publications that appeared between 2007 and 2014 in Chinese journals (seven articles) and French journals (two articles), and we added up the quotations from Chinese, French, and English texts.

Out of the whole body of texts there were 299 bibliographical references, distributed as follows: $64 \%$ were in Chinese, $19 \%$ in French, and $17 \%$ in English. ${ }^{(20)}$ Over the whole seven-year period, it turns out that the references in non-Chinese languages occupy a large proportion and the references in French alone amount to a significant one out of five. If one considers the two publications in French alone, the 42 quoted references are shared as follows: $60 \%$ in French, $21 \%$ in Chinese, and 19\% in English. In the case of the seven publications in Chinese alone, the 257 quoted references are shared as follows: $71 \%$ in Chinese, $17 \%$ in English, and 12\% in French. The proportion of references in French matches the size of the French support for the publication. This is certainly not surprising. It is the outcome of the writer's conscious adaptation to the expectations of the different institutions. We believe that this shows the flexibility of the writer who knows the expectations of this or that journal and bends to accommodate them in order to see his work published. In sum, our hypothesis is that by being affiliated to two different academic worlds, our interviewees are enabled to develop strategies for existing simultaneously in both of them.

An illustrative comparison is provided by a recent publication aiming at stimulating a dialogue between French and Chinese sociologists specialising in economic sociology (Roulleau-Berger and Liu 2014). Out of 12 contributions by Chinese writers, there are only three references to works by French authors, and which are old to say the least: Jacques Ellul's La Société technologique (1965), Pierre Bourdieu's La Distinction (1979), and Alain Touraine's writing on the method of sociological intervention. By way of contrast, English language sociology is quoted in abundance. Those 12 contributions are all by senior figures who occupy well-established positions in their universities, unlike the junior researchers considered in this article. In our view, the latters' initial study periods in France during their years of training, provided that they are followed by regular scientific exchanges that could take the form of shared research programmes, for example, offer opportunities for lasting epistemological cross-fertilisation in the future.

\section{Conclusion}

The qualitative enquiry conducted here is based on a body of young Chinese researchers trained in French social sciences, most of whom were financially supported and intend to pursue a university career in China. It shows a number of differences due to the move overseas, in terms of both place of training and epistemological issues. In France the interviewees experienced scientific practices quite different from those they had known in China, opening a lot of room for individual autonomy and for a fuller acquaintance with intellectual traditions, while at the same time assimilating concepts forged in the European context, which for some of them were not directly applicable to the Chinese context. From that point of view, movement between the different areas of science is a salutary experience, since it ensures the defamiliarisation of the categories of thought and reminds us that all intellectual production must be seen in its context (Espagne and Werner 1988; Bourdieu 2002).

Nonetheless, the testing demands faced by these interviewees in their professional integration do not seem to have had any specifically epistemological dimension. What they showed was their greater or lesser mastery of the requisite know-how and professional strategies. In sum, the major Chinese universities - although more should probably be said on the diversity of situations in relation to the establishments concerned - have aligned their patterns for recruitment, assessment, and promotions with those of the English-speaking world, which gave rise to considerable debate in the early 2000s (Merle 2004). The results presented in this article would gain from

20. It is really the language of the reference that is taken into account. Certainly, the Chinese references may include some to works originally published in another language, just as there may be references in French to the titles of English-language writers. But these instances are very marginal. 
further in-depth enquiries, such as an analysis of the corpus of course syllabuses produced by some of our young Chinese colleagues trained in France.

I Translated by Jonathan Hall.

I Gilles Guiheux is a professor at Cessma, Université Paris Diderot, Sorbonne Paris Cité. Cessma, Université Paris Diderot, 75205 Paris Cedex 13, France (gilles.guiheux@univ-paris-diderot.fr).
Wang Simeng is a permanent research fellow at the National Center for Scientific Research (CNRS). Cermes3, CNRS, 7, rue Guy Môquet, BP 8, 94801 Villejuif Cedex, France (simeng.wang@cnrs.fr).

Manuscript received on 11 May 2018. Accepted on 6 November 2018.

\section{Annex - Table showing the overall university careers of the interviewees}

\begin{tabular}{|c|c|c|c|c|c|}
\hline & $\begin{array}{l}\text { Dates of study } \\
\text { in France* }\end{array}$ & $\begin{array}{c}\text { Number of } \\
\text { years studying } \\
\text { in France* }\end{array}$ & $\begin{array}{l}\text { Discipline of doctoral } \\
\text { study in France }\end{array}$ & $\begin{array}{l}\text { Discipline studied } \\
\text { in China }\end{array}$ & $\begin{array}{l}\text { Financial support } \\
\text { for doctorate } * * * *\end{array}$ \\
\hline 11 & 2007-2014 & 7 & anthropology & French language and literature & doctoral contract \\
\hline 12 & $2010-2018$ & 8 & anthropology & management & $\mathrm{CSC}$ \\
\hline 13 & $2012-2017$ & 5 & sociology & management & $\mathrm{CSC}$ \\
\hline 14 & $2001-2007$ & 6 & sociology & sociology & doctoral contract \\
\hline 15 & 2009-2014 & 5 & history & history & $\mathrm{CSC}$ \\
\hline 16 & $2005-2013$ & 8 & history of religions & history & CSC \\
\hline 17 & $2000-2011$ & 11 & economics & $* * *$ & CSC \\
\hline 18 & 2008-2014 & 6 & sociology & sociology & CSC \\
\hline 19 & 2004-2012 & 8 & urban studies & urban studies & self-financed \\
\hline $\mid 10$ & $2010-2014$ & 4 & sociology & sociology & $\mathrm{CSC}$ \\
\hline 111 & 2015-1018 & 3 & sociology & sociology & $\mathrm{CSC}$ \\
\hline 112 & $2008-2014$ & 6 & geography & history and geography & $\mathrm{CSC}$ \\
\hline 113 & 2004-2017 & 13 & sociology, migration & public administration & self-financed \\
\hline 114 & 2011-2016 & 5 & sociology & sociology & CSC \\
\hline I15 & $2002-2013$ & 11 & history & management & self-financed \\
\hline I16 & $2003-2016$ & 13 & sociology & ethnology & doctoral contract \\
\hline I17 & $2005-2012$ & 7 & political science & political science & self-financed \\
\hline 118 & $2009-2018^{* *}$ & 9 & sociology & $* * *$ & self-financed \\
\hline 119 & 2016-2019** & 3 & philosophy & literature & self-financed \\
\hline 120 & $2007-2018^{* *}$ & 11 & sociology & history and sociology & doctoral contract \\
\hline 121 & $2011-2020 * *$ & 9 & anthropology & literature & CSC \\
\hline 122 & $2011-2018^{* *}$ & 7 & language teaching & French language & $\mathrm{CSC}$ \\
\hline 123 & $2016-2020 * *$ & 4 & sociology & sociology & $\mathrm{CSC}$ \\
\hline
\end{tabular}

* This refers to the number of years of study at a French university, including a thesis. Before their thesis some students had obtained a Bachelor's degree and a Master's in France.

** Thesis still in process. We indicate the year of its expected completion.

*** Students who have not followed any university course in China, and have had all their university training in France.

**** Four kinds of financial support are specified here: self-financing, French university doctoral contract, another French scholarship, and support from the CSC.

Note: The questionnaires were received between December 2017 and February 2018. 


\section{References}

ALATAS, Syed Farid. 2003. "Academic Dependency and the Global Division of Labour in the Social Sciences." Current Sociology 51(6): 599-613.

BECKER, Howard S. 2002. Les ficelles du métier. Comment conduire sa recherche en sciences sociales (Tricks of the trade: How to think about your research while you're doing it). Paris: La Découverte.

BOURDIEU, Pierre. 2000. "Les conditions sociales de la circulation internationale des idées" (The social conditions of the international circulation of Ideas). Actes de la recherche en sciences sociales 145: 3-8.

BOURDIEU, Pierre. 2003. "L'objectivation participante" (Participant objectivation). Actes de la recherche en sciences sociales 150: 43-58.

BOURDIEU, Pierre. 2004. Esquisse pour une auto-analyse (Sketch for a self-analysis). Paris: Raisons d'agir.

BOURGOUIN, France. 2011. "Des individualistes globaux: ruptures et discontinuités dans les familles d'élites africaines transnationales" (Global individualists: Breaks and continuities in transnational African elite families). Autrepart 2011/1-2 (57-58): 299-314.

CASADEVALL, Arturo, and FANG Ferric C. 2014. "Causes for the Persistence of Impact Factor Mania." MBio 5(2).

CHEVRIER, Yves. 2003. "Les Aires culturelles dans les sciences de l'homme et de la société: questions pour une prospective" (Cultural Areas in human and social sciences). Paper read at the conference: Les Aires culturelles dans les sciences de l'homme et de la société: questions pour une prospective (Cultural Areas in human and social sciences), CNRS, Gif sur Yvette 24-25-26 September 2003.

CONTAT, Odile, and Anne-Solweig GREMILLET. 2015. "Publier: à quel prix? Étude sur la structuration des coûts de publication pour les revues françaises en SHS" (Publishing: at what cost? Study on the structuration of publication costs for French SHS journals) Revue française des sciences de l'information et de la communication 7.

COULON, Alain. 1997. Le métier d'étudiant (Student, a Profession). Paris: PUF.

DASSA, Michèle, Christine KOSMOPOULOS, and Denise PUMAIN. 2010 "JournalBase. Comparer les bases de données scientifiques internationales en sciences humaines et sociales" (JournalBase. Comparing international scientific databases in human and social sciences). Cybergeo: European Journal of Geography. http://journals.openedition.org/cybergeo/22864 (accessed on 19 January 2018).

DEDIEU, Jean-Philippe. 2003. "Les élites africaines, enjeu de la diplomatie scientifique des États-Unis" (African Elites: a challenge for the United States' scientific diplomacy). Politique étrangère (Foreign diplomacy) 1: 119-31.

DEROUET, Jean-Louis, Philippe SAVOIE, Yiping HUO, and Jean-Émile CHARLIER. 2017. La formation des élites en Chine et en France (XVIIe-XXIe siècles): les apports de regards croisés: sociologie, histoire, philosophie politiques (Elite formation in China and France). Louvain-La-Neuve: Academia-L'Harmattan.

DIA, Hamidou. 2015. "Les diplômés en langue arabe au sein de l'élite sénégalaise: du symbolique à l'académique" (Arab language graduates in Senegalese elite circles). Cahiers de la recherche sur l'éducation et les savoirs 14: 187-206.

ESPAGNE, Michel, and WERNER Michael (eds.). 1988. Transferts. Les relations interculturelles dans l'espace franco-allemand (XVIIle-XIXe siècles) (Transfers. Intercultural relations in the Franco-German area). Paris: Éditions Recherche sur les civilisations.
GARNEAU, Stéphanie, and Sylvie MAZZELLA. 2013. "Transformations des mobilités étudiantes sud-nord: approches démographiques et sociologiques" (The transformations of South-North student mobility). Cahiers québécois de démographie 42(2): 183-200.

GERARD, Étienne, and Jean-François CORNU. 2013. "Dynamiques de mobilité étudiante Sud-Nord: une approche par les pôles internationaux de formation de l'élite' scientifique mexicaine" (Dynamics of South-North student mobility). Cahiers québécois de démographie 42(2): 241-72.

GERARD, Étienne, and Anne-Catherine WAGNER. 2015. "Introduction: Élites au Nord, élites au Sud: des savoirs en concurrence ?" (Introduction: Competing knowledge from North and South elites?). Cahiers de la recherche sur l'éducation et les savoirs 14: 7-24.

GOLD, Thomas, Doug GUTHRIE, and David WANK (eds.). 2002. Social Connections in China: Institutions, Culture, and the Changing Nature of Guanxi. Cambridge, Mass: Cambridge University Press.

GOSSAERT, Vincent. 2007. "L'invention des 'religions' en Chine moderne" (The Invention of 'Religions' in Modern China). In Anne Cheng (ed.), La pensée en Chine aujourd'hui (Chinese thought today). Paris: Gallimard. 185-213.

HEIMER, Maria, and Stig THØGERSEN (eds.). 2006. Doing Fieldwork in China. Honolulu: University of Hawaii Press.

HUANG, Futao. 2007. "L'internationalisation de l'enseignement supérieur à l'ère de la mondialisation: ses répercussions en Chine et au Japon" (The Internationalisation of higher education in the global era: Impacts in China and Japan). Politiques et gestion de l'enseignement supérieur 19(1): 4964.

HUANG, He. 2010. "China's Historical Encounter with Western Sciences and Humanities." In Michael Kuhn and Doris Weidemann (eds.), Internationalisation of the Social Sciences. Bielefeld: Transcript. 21-44.

KUHN, Michael, and Doris WEIDEMANN. "Internationalization of the Social Sciences: Introduction." In Michael Kuhn and Doris Weidemann (eds.), Internationalisation of the Social Sciences. Bielefeld: Transcript. 11-20.

LONGUENESSE, Elisabeth, and François SIINO. 2005. "Aires culturelles et pluridisciplinarités. Quel enjeu pour les sciences sociales ?" (Cultural areas and pluridisciplinarity). Revue du monde musulman et de la Méditerranée 105-106: 7-12.

MAZZELLA, Sylvie (ed.). 2009. La mondialisation étudiante. Le Maghreb entre Nord et Sud (Student globalisation. The position of Mahgreb between North and South). Paris: Karthala.

MERLE, Aurore. 2004. "La réforme des universités et de l'enseignement supérieur en Chine: le débat autour de l'université de Pékin" (The reform of universities and higher education in China). Lettre du CEFC, Nouvelles de Chine, March-April.

O'BRIEN, Kevin J. 2006. "Discovery, Research (Re)design, and Theory Building." In Maria Heimer and Stig Thøgersen (eds.), Doing Fieldwork in China. Honolulu: University of Hawaii Press: 27-41.

ROCCA, Jean-Louis (ed.). 2008. La société chinoise vue par ses sociologues (Chinese society seen through its sociologists). Paris: Presses de Sciences Po.

ROULLEAU-BERGER, Laurence. 2015. "Sciences sociales 'postoccidentales': de l'Asie à l'Europe" ('Post-Western' social sciences: From Asia to Europe). Socio 5: 9-23.

ROULLEAU-BERGER, Laurence. 2011. Désoccidentaliser la sociologie. L'Europe au miroir de la Chine (De-Westernising sociology. Europe in the mirror of China). La Tour d'Aigues: Éditions de l'Aube.

ROULLEAU-BERGER, Laurence, GUOYuhua, LI Peilin, and LIU Shiding (eds.). 2008. La nouvelle sociologie chinoise (The new Chinese sociology). Paris: CNRS éditions. 
ROULLEAU-BERGER, Laurence, and LIU Shiding. 2014. Sociologies économiques française et chinoise: regards croisés (French and Chinese economic sociology). Lyon: ENS éditions.

SEGLEN, Per O. 1997. "Why the Impact Factor of Journals Should Not Be Used for Evaluating Research." BMJ 314(7079): 498-502.

SPRING, Joel. 2014. Globalization of Education: An Introduction. New York: Routledge.

SZANTON, David L. 2003. "The Origin, Nature and Challenges of Area Studies in the United States." In David L. Szanton (ed.). The Politics of Knowledge: Area Studies and the Disciplines. Stanford: Stanford University Press. 1-33.
ZAKI, Lamia. 2006. "L'écriture d'une thèse en sciences sociales: entre contingences et nécessités" (Writing a PhD thesis in social sciences). Genèses 4-5: 112-25.

ZHANG, Letian. 2008. "La crise de la recherche fondamentale. Recherche académique, logique du marché ou intervention étatique" (The crisis of fundamental research:Academic research, market logics or state intervention). In Jean-Louis Rocca (ed.), La société chinoise vue par ses sociologues (Chinese society seen through its sociologists). Paris: Presses de Sciences Po. 289-307. 